\title{
LEVEL PENGGUNAAN Aspergillus oryzae PADA FERMENTASI KULIT UBI KAYU (Manihot utilissima) TERHADAP KANDUNGAN HCN, TDN DAN pH
}

\section{Level of Use of Aspergillus oryzae in Fermentation of Cassava Peels (Manihot utilissima) to HCN, TDN and $\mathrm{pH}$}

\author{
Grapevin Riviesa Azalea Putri ${ }^{1)}$, Siti Chuzaemi²) \\ 1) Mahasiswa Fakultas Peternakan, Universitas Brawijaya Jalan Veteran, Ketawanggede, Kec. Lowokwaru, \\ Kota Malang, Jawa Timur, Indonesia 65145 \\ ${ }^{2)}$ Dosen Fakultas Peternakan, Universitas Brawijaya Jalan Veteran, Ketawanggede, Kec. Lowokwaru, Kota \\ Malang, Jawa Timur, Indonesia 65145 \\ Email: grapevin.rap@gmail.com \\ Diterima Pasca Revisi: 20 Februari 2021 \\ Layak Diterbitkan: 1 Maret 2021
}

\begin{abstract}
ABSTRAK
Tujuan dari penelitian ini adalah untuk mengetahui dan mengevaluasi pengaruh level penggunaan Aspergillus oryzae pada fermentasi kulit ubi kayu (Manihot utilissima) terhadap nilai kandungan $\mathrm{HCN}$, TDN dan $\mathrm{pH}$. Metode penelitian menggunakan Rancangan Acak Lengkap (RAL) dengan 4 perlakuan yang diulang 3 kali. Perlakuan terdiri dari P0 (kulit ubi kayu + Aspergillus oryzae 0\% difermentasi 96 jam), P1 (kulit ubi kayu + Aspergillus oryzae 1\% difermentasi 96 jam), P2 (kulit ubi kayu + Aspergillus oryzae 2\% difermentasi 96 jam), dan P3 (kulit ubi kayu + Aspergillus oryzae 3\% difermentasi 96 jam). Variabel yang diukur adalah kandungan HCN, TDN dan $\mathrm{pH}$. Hasil penelitian menunjukkan bahwa level penggunaan konsentrasi Aspergillus oryzae memberikan memberikan pengaruh sangat berbeda nyata $(\mathrm{P}<0,01)$ terhadap $\mathrm{HCN}$, TDN dan $\mathrm{pH}$. Perlakuan terbaik didapatkan pada perlakuan $\mathrm{P} 3$ (kulit ubi kayu + Aspergillus oryzae 3\% difermentasi 96 jam) dengan nilai HCN 55,82 mg/kg, TDN $72,92 \%$ dan $\mathrm{pH} 5,23$. Kesimpulan dari penelitian ini adalah fermentasi kulit ubi kayu menggunakan konsentrasi Aspergillus oryzae 3\% yang difermentasi selama 96 jam merupakan perlakuan terbaik untuk nilai $\mathrm{pH}$ dan meningkatkan nilai TDN serta menurunkan nilai HCN.
\end{abstract}

Kata kunci: Kulit ubi kayu, fermentasi, HCN, TDN, pH

How to Cite:

Putri, G. R. A., \& Chuzaemi, S. (2021). Level Penggunaan Aspergillus Oryzae pada Fermentasi Kulit Ubi Kayu (Manihot Utilissima) Terhadap Kandungan HCN, TDN dan pH. Jurnal Nutrisi Ternak Tropis 4 (1) 60-69
*Corresponding author:

Grapevin Riviesa Azalea Putri

Email: grapevin.rap@gmail.com

Fakultas Peternakan, Universitas Brawijaya Jalan Veteran, Ketawanggede, Kec. Lowokwaru, Kota Malang, Jawa Timur, Indonesia 65145 


\begin{abstract}
The purpose of this study was to determine and evaluate the effect of the level of Aspergillus oryzae use on cassava peels fermentation (Manihot utilissima) on the value of $H C N, T D N$ and $p H$ content. The research method used a completely randomized design (CRD) with 4 treatments repeated 3 times. The treatments consisted of PO (cassava peel + Aspergillus oryzae 0\% fermented 96 hours), P1 (cassava peel + Aspergillus oryzae 1\% fermented 96 hours), P2 (cassava peel + Aspergillus oryzae 2\% fermented 96 hours), and P3 (cassava peel + Aspergillus oryzae $3 \%$ fermented 96 hours). The variables measured were the content of $H C N, T D N$ and $\mathrm{pH}$. The results showed that the level of use of the Aspergillus oryzae concentration had a very significant effect $(P<0.01)$ on HCN, TDN and $\mathrm{pH}$. The best treatment was obtained in the P3 treatment (cassava peel + Aspergillus oryzae 3\% fermented 96 hours) with an HCN value of $55.82 \mathrm{mg} / \mathrm{kg}$, TDN 72.92\% and $\mathrm{pH} 5.23$. The conclusion of this study is that the fermentation of cassava peels using a concentration of Aspergillus oryzae 3\% fermented for 96 hours is the best treatment for the $\mathrm{pH}$ value and increases the TDN value and reduces the HCN value.
\end{abstract}

Keywords: Manihot utilissima, fermentation, $H C N$, TDN, $p H$

\section{PENDAHULUAN}

Permasalahan yang dihadapi oleh pelaku usaha pengembangan ternak ruminansia terdapat pada pengadaan pakan. Pakan merupakan faktor yang utama dalam berjalannya sistem peternakan. Pada musim kemarau ketersediaan pakan dan kualitas pakan rendah. Hal tersebut akan berdampak pada penurunan daya cerna dan tidakseimbangnya nutrien untuk pertumbuhan mikroba rumen yang mendukung produksi ternak (Tanuwiria, Mushawwir dan Yulianti, 2007).

Alternatif yang dapat dimanfaatkan sebagai pakan adalah hasil samping pertanian seperti ubi kayu karena ketersediaannya yang melimpah di Indonesia. Luas panen ubi kayu di Indonesia pada tahun 2018 adalah 959.926 ribu hektar dan produksi yang dicapai sebesar 32,8 juta ton dengan produktivitas sebesar 21,85 ton/ha (Yuliati, Nasir, dan Subagiarta, 2019). Menurut Darmawan (2006) limbah kulit yang dihasilkan lebih kurang $16 \%$ dari total produksi ubi kayu yaitu sekitar 5,248 juta ton. Melimpahnya produksi limbah tanaman pangan tersebut dapat dimanfaatkan sebagai sumber pakan ruminansia (Syamsu dan Abdullah, 2009). Kandungan nutrisi yang terkandung dalam ubi kayu terdiri atas kadar air sekitar $60 \%$, pati $35 \%$, serat kasar $2,5 \%$, kadar protein $1 \%$, kadar lemak 0,5\% dan kadar abu $1 \%$ (Anonim, 2011). Menurut Feliana, Laenggeng dan Dhafir (2014), kandungan nutrisi yang terdapat dalam limbah kulit ubi kayu yaitu protein $2,45 \%$, serat kasar $0,73 \%$, lemak kasar 0,83\%, dan karbohidrat 29,13\%. Nilai TDN pada kulit ubi kayu yaitu sebesar 56,91\% (Antari dan Umiyasih, 2009).

Pemanfaatan kulit ubi kayu sebagai pakan ternak masih terbatas dikarenakan adanya kandungan sianida yang dapat meracuni ternak. Menurut Wangari (2013) kandungan HCN yang ada dalam kulit ubi kayu berkisar antara $70,45 \mathrm{mg} / \mathrm{kg}$ hingga $115,65 \mathrm{mg} / \mathrm{kg}$. Salah satu upaya pengolahan yang dapat dilakukan untuk mengurangi racun sianida adalah proses fermentasi. Selain menurunkan kandungan asam sianida, proses fermentasi juga dapat meningkatkan kandungan energi, protein, serat kasar serta meningkatkan daya cerna bahan pakan berkualitas rendah (Putri dan Hersoelistyorini, 2012). Prinsip fermentasi adalah mengaktifkan pertumbuhan dan metabolisme mikroorganisme sehingga meningkatkan daya cerna karena adanya penurunan jumlah serat kasar sehingga nilai kecernaan pakan menigkat (Sjofjan et al., 2020). Penggunaan Aspergillus niger 2\% pada proses fermentasi merupakan 
perlakuan terbaik dalam meningkatkan kecernaan bahan kering dan bahan organik (Nurlaili, Suparwi dan Sutardi, 2013). Berdasarkan penelitian Yuliana dan Chuzaemi (2019), perlakuan terbaik fermentasi pada ampas putak dengan menggunakan Aspergillus oryzae memberikan hasil optimal terhadap peningkatan kualitas fisik dan kualitas kimia pada lama waktu fermentasi 96 jam. Berdasarkan uraian di atas maka perlu dilakukan penelitian mengenai pengaruh level penggunaan Aspergillus oryzae dengan persentase yang berbeda pada fermentasi kulit ubi kayu terhadap kandungan $\mathrm{HCN}$, TDN (Total Digestible Nutrient) dan $\mathrm{pH}$.

\section{MATERI DAN METODE}

\section{Lokasi dan Waktu}

Penelitian ini dilakukan di Laboratorium Nutrisi dan Makanan Ternak Fakultas Peternakan Universitas Brawijaya Malang dan Laboratorium Jurusan Kimia Fakultas MIPA Universitas Brawijaya Malang.

Materi

Materi penelitian yang digunakan adalah kulit ubi kayu (Manihot utilissima), Aspergillus oryzae, bahan analisis proksimat dan bahan analisis HCN.

\section{Metode}

Metode penelitian yang digunakan adalah metode percobaan di laboratorium menggunakan Rancangan Acak Lengkap (RAL) dengan 4 perlakuan dan 3 kali ulangan sehingga terdapat 12 unit. Metode pengukuran HCN dilakukan berdasarkan Hermanto dan Fitriani (2018). Pengukuran kandungan TDN untuk kelas bahan sumber energi bagi ternak domba dihitung berdasarkan rumus Hartadi dkk (1980). Nilai pH diukur berdasarkan Allaily, Ramly dan Ridwan (2011). Perlakuan yang dilakukan adalah sebagai berikut:

P0 : Kulit ubi kayu + Aspergillus oryzae 0\% difermentasi selama 96 jam
P1 : Kulit ubi kayu + Aspergillus oryzae $1 \%$ difermentasi selama 96 jam

P2 : Kulit ubi kayu + Aspergillus oryzae 2\% difermentasi selama 96 jam

P3 : Kulit ubi kayu + Aspergillus oryzae 3\% difermentasi selama 96 jam

\section{Prosedur Pembuatan Fermentasi Kulit Ubi Kayu}

1. Disiapkan alat yang akan digunakan.

2. Disiapkan kulit ubi kayu.

3. Dicuci kulit ubi kayu kemudian dipotong kecil-kecil 1-3 cm (Muhiddin, Juli dan Aryantha, 2001).

4. Diangin-anginkan kulit ubi kayu tersebut selama 2 hari (KA 65\%) (Akhadiarto, 2009).

5. Ditimbang kulit ubi kayu sebanyak 100 gram (Muhiddin dkk, 2001).

6. Ditambahkan inokulum Aspergillus oryzae $0 \%, 1 \%, 2 \%$ dan $3 \%$.

7. Dikemas dengan kantong plastik (fermentor) secara aseptis.

8. Difermentasi selama 96 jam secara aerob.

9. Dikeringkan dengan oven suhu $60^{\circ} \mathrm{C}$ kemudian digiling dengan ketebalan 1 $\mathrm{mm}$.

\section{Variabel yang diamati terdiri atas:}

Variabel yang diamati untuk keberhasilan penelitian ini adalah kandungan $\mathrm{HCN}$, TDN dan $\mathrm{pH}$.

\section{Analisis Data}

Data yang diperoleh dianalisis statistik menggunakan analisis ragam (ANOVA) dari Rancangan Acak Lengkap (RAL). Selanjutnya untuk mengetahui perbedaan antar perlakuan dilakukan dengan menggunakan Uji Jarak Berganda Duncan (UJBD) (Steel dan Torrie, 1993).

\section{HASIL DAN PEMBAHASAN}

\section{Kandungan HCN}

Data kandungan asam sianida $(\mathrm{HCN})$ pada kulit ubi kayu pada berbagai variasi konsentrasi Aspergillus oryzae dapat dilihat pada Tabel 1. 
Tabel 1. Rataan nilai HCN Hasil Fermentasi Kulit Ubi Kayu

\begin{tabular}{cc}
\hline Perlakuan & HCN $(\mathrm{mg} / \mathrm{kg})$ \\
\hline P0 & $72,07^{\mathrm{c}}$ \\
P1 & $61,99^{\mathrm{b}}$ \\
P2 & $49,99^{\mathrm{a}}$ \\
P3 & $55,82^{\mathrm{ab}}$ \\
\hline
\end{tabular}

Keterangan: Superskrip yang berbeda pada kolom yang sama menunjukkan perbedaan yang sangat nyata $(\mathrm{P}<0,01)$ terhadap nilai $\mathrm{HCN}$ fermentasi kulit ubi kayu.

Hasil analisis statistik pada Tabel 1 menunjukkan bahwa perlakuan variasi konsentrasi Aspergillus oryzae pada fermentasi kulit ubi kayu memberikan pengaruh yang sangat nyata $(\mathrm{P}<0,01)$ terhadap nilai kandungan $\mathrm{HCN}$. Hasil Uji Jarak Berganda Duncan menunjukkan bahwa rataan kadar HCN tertinggi adalah perlakuan P0 yang berbeda sangat nyata $(\mathrm{P}<0,01)$ dengan perlakuan lainnya.

Nilai kandungan $\mathrm{HCN}$ terendah adalah perlakuan P2 yang berbeda sangat nyata dengan perlakuan $\mathrm{P} 0$ dan $\mathrm{P} 1$, namun tidak berbeda sangat nyata terhadap perlakuan P3. Kadar HCN pada perlakuan P1, P2 dan P3 mengalami penurunan dibandingkan dengan P0 yang semula 72,07 $\mathrm{mg} / \mathrm{kg}$ menjadi $61,99 \mathrm{mg} / \mathrm{kg} ; 49,99 \mathrm{mg} / \mathrm{kg}$ dan 55,82 mg/kg. Menurut Wangari (2013), kandungan HCN pada kulit ubi kayu dapat mencapai $115,65 \mathrm{mg} / \mathrm{kg}$. Dari hal tersebut dapat dilihat bahwa perlakuan fisik sebelum fermentasi berupa pencucian, pelayuan dan pemotongan partikel juga dapat menurunkan kandungan $\mathrm{HCN}$ pada $\mathrm{PO}$ menjadi $72,07 \mathrm{mg} / \mathrm{kg}$. Hal tersebut sesuai dengan Santi dkk (2015) yang menyatakan bahwa pemotongan kulit ubi kayu menjadi ukuran yang lebih kecil juga mempercepat proses penguapan dan mempercepat pengurangan sianida pada kulit ubi kayu. Pada penelitian ini, kulit ubi kayu yang diangin-anginkan terlebih dahulu juga diduga dapat menurunkan nilai $\mathrm{HCN}$.

Stephanie dan Purwadaria (2013) menyatakan bahwa $\mathrm{HCN}$ bersifat mudah larut dalam air dan mudah lepas ke udara. Hasil studi yang dilakukan mengalami penuruan $\mathrm{HCN}$ sebesar $23 \%$. Hasil tersebut berbeda dengan yang dilaporkan Muhiddin,
Djide dan As'ad (2013) dengan perlakuan inokulum isolat kapang mampu menurunkan HCN sebesar $41 \%$. Perbedaan penurunan $\mathrm{HCN}$ tersebut dijelaskan oleh Simbolon dkk (2016) kadar HCN juga dapat menurun karena adanya enzim yang mampu mendegradasi linamarin pada saat proses fermentasi. Pemberian variasi konsentrasi jamur pada perlakuan P1, P2, dan P3 mampu menurunkan kandungan $\mathrm{HCN}$ pada fermentasi kulit ubi kayu dikarenakan semakin tinggi dosis jamur yang digunakan maka kandungan $\mathrm{HCN}$ juga semakin rendah.

Hal tersebut diperjelas oleh Aisjah dan Abun (2012) yang menyatakan bahwa tingkat dosis berkaitan dengan besaran populasi mikroba yang berpeluang menentukan cepat tidaknya perkembangan mikroba dalam menghasilkan enzim untuk merombak substrat sehingga pada gilirannya berpengaruh terhadap produk akhir. Semakin tinggi dosis inokulum, semakin banyak populasi mikroba (kapang) dan komponen substrat yang dirombak (Adli dan Sjofjan, 2020). Kapang Aspergillus oryzae dikenal sebagai kapang yang mampu menghasilkan bermacam jenis enzim diantaranya $\alpha$-amilase, $\alpha$-glaktosidase, glutaminase, proteinase, dan $\beta$-glukosidase (Suryani, Zain, Jamarun dan Ningrat, 2015).

Fermentasi menyebabkan terjadinya pemecahan senyawa linamarin menjadi sianida bebas yang disebabkan adanya akitivitas enzim linamarase dari umbi ubi kayu. Reduksi HCN ini dengan metode fermentasi disebabkan adanya peningkatan konsentrasi mikroorganisme selama fermentasi tetap sehingga mempercepat kerusakan glikosida sianogenik (Sari dan 
Astili, 2018). Hasil fermentasi tersebut akan menurunkan HCN karena adanya aktivitas mikroorganisme yang memecah heksosa menjadi asam, sehingga heksosa tersebut tidak lagi berperan sebagai pengikat (Muhiddin dkk, 2013).

Pada penelitian ini kulit ubi kayu hasil fermentasi mengalami penurunan $\mathrm{HCN}$ lebih rendah dibandingkan penelitian Muhiddin dkk (2013) yaitu sebesar 23\%. Untuk lebih mengoptimalkan penurunan kadar $\mathrm{HCN}$ maka perlu adanya penambahan akselerator seperti urea. Penambahan urea akan membuat pertumbuhan mikroba semakin optimal dengan memanfaatkan nitrogen dalam urea sehingga terjadi peningkatan jumlah mikroba untuk mempercepat kerusakan glikosida sianogenik, menginaktivasi enzim linamarase sehingga tidak bisa mengkatalisis pembentukan $\mathrm{HCN}$ dan menguraikan racun menjadi asam organik (Rasulu, Yuwono dan Kusnadi, 2012).

\section{Kandungan TDN}

Kualitas energi pakan dapat diukur melalui TDN (Total Digestible Nutrient). Kandungan TDN untuk bahan kelas sumber energi bagi ternak domba dihitung dengan rumus Hartadi dkk (1980) berdasarkan data analisis proksimat. Hasil analisis proksimat disajikan pada Tabel 2.
Kandungan TDN pada kulit ubi kayu yang difermentasi dengan konsentrasi Aspergillus oryzae berbeda dapat dilihat pada Tabel 3. Hasil analisis ragam memperlihatkan bahwa hasil fermentasi kulit ubi kayu dengan variasi konsentrasi Aspergillus oryzae berpengaruh sangat nyata $(\mathrm{P}<0,01)$ terhadap kandungan TDN hasil fermentasi. Berdasarkan hasil Uji Jarak Berganda Duncan, diketahui bahwa nilai TDN tertinggi adalah perlakuan P3 yang menunjukkan pengaruh sangat nyata dibandingkan $\mathrm{P} 0$ dan $\mathrm{P} 1$, namun tidak berpengaruh sangat nyata terhadap $\mathrm{P} 2$. Nilai TDN terendah adalah perlakuan P0 yang menunjukkan pengaruh sangat nyata terhadap perlakuan P2 dan P3, namun tidak ada pengaruh sangat nyata dengan perlakuan P1. Nilai rataan kandungan TDN dari yang tertinggi hingga terendah adalah $\mathrm{P} 3 \mathrm{72,92 \%}$; P2 71,51\%; P1 69,94\%; P0 68,58. Data tersebut menunjukkan bahwa kandungan TDN fermentasi kulit ubi kayu semakin meningkat seiring bertambahnya kadar jamur Aspergillus oryzae yang digunakan karena terdapat perombakan serat kasar oleh mikroba starter menghasilkan karbohidrat yang mudah dicerna sehingga nilai TDN menjadi meningkat. Semakin tinggi konsentrasi starter yang digunakan maka kandungan TDN juga semakin meningkat.

Tabel 2. Hasil Analisis Proksimat Fermentasi Kulit Ubi Kayu

\begin{tabular}{ccccccc}
\hline Perlakuan & BK & BO* $^{*}$ & PK $^{*}$ & LK $^{*}$ & SK $^{*}$ & BETN* \\
\hline P0 & 19,70 & 93,10 & 7,15 & 2,17 & 25,65 & 58,13 \\
P1 & 19,59 & 93,07 & 5,47 & 2,40 & 23,78 & 61,41 \\
P2 & 21,34 & 93,08 & 4,07 & 2,54 & 21,63 & 64,83 \\
P3 & 20,28 & 93,39 & 3,95 & 1,81 & 21,65 & 65,97 \\
\hline
\end{tabular}

Keterangan: * Berdasarkan 100\% BK

Tabel 3. Rataan nilai TDN hasil fermentasi kulit ubi kayu

\begin{tabular}{cc}
\hline Perlakuan & Rata-rata (\%) \\
\hline P0 & $68,58 \pm 0,83^{\mathrm{a}}$ \\
P1 & $69,94 \pm 1,06^{\mathrm{ab}}$ \\
P2 & $71,51 \pm 0,37^{\mathrm{bc}}$ \\
P3 & $72,92 \pm 0,51^{\mathrm{c}}$ \\
\hline
\end{tabular}

Keterangan : Superskrip yang berbeda pada kolom yang sama menunjukkan perbedaan yang sangat nyata $(\mathrm{P}<0,01)$ terhadap nilai TDN hasil fermentasi kulit ubi kayu. 
Hal tersebut juga didukung oleh Hatma, Tampoebolon dan Prasetiyono (2018) yang menyatakan bahwa semakin tinggi aras starter yang digunakan maka kandungan TDN juga semakin tinggi. Hal tersebut dikarenakan pada perlakuan terdapat perombakan serat kasar oleh mikroba starter menghasilkan karbohidrat yang mudah dicerna sehingga nilai TDN menjadi meningkat. Menurut Amrullah dkk (2019), peningkatan nilai TDN dapat terjadi karena adanya penurunan kandungan serat kasar yang disebabkan oleh aktivitas mikroba (Aspergillus niger) saat proses fermentasi yang menurunkan kadar serat substrat sehingga kecernaannya meningkat.

Penelitian Wijayanti, Wahyono dan Surono (2012) melaporkan bahwa kandungan PK dan SK pakan juga akan mempengaruhi nilai kecernaan pakan tersebut. Hal tersebut juga didukung oleh Dewi, Suryani, dan Mudita (2020) yang menyatakan bahwa peningkatan nilai TDN juga dipengaruhi oleh PK, LK, SK dan BETN. Hasil studi menunjukkan bahwa kandungan PK mengalami penurunan. Hal tersebut diduga karena protein asal mikrobia tidak terbaca sebagai $\mathrm{N}$ asal NPN sehingga tidak meningkatkan kandungan protein kasar meskipun mempunyai kandungan inokulum terbanyak (Hersoelistyorini dkk, 2012).

Kurangnya penambahan zat lain seperti urea juga dapat memicu terjadinya penurunan nilai PK karena populasi mikroba yang dihasilkan dari proses fermentasi mulai mengalami kematian akibat kandungan nutrien dalam medium semakin berkurang sehingga nitrogen yang tersedia dimanfaatkan sebagian saja untuk pertumbuhan Aspergillus oryzae dan akhirnya menguap. Adanya penambahan urea pada proses fermentasi akan dimanfaatkan oleh mikroba untuk pertumbuhan. Menurut Simbolon dkk (2016), penambahan urea dapat merenggangkan ikatan antara selulosa dan lignin sehingga mikroba dapat dengan mudah mendegradasi serat pada kulit ubi kayu dan akhirnya mampu meningkatkan kecernaan. Menurut Ahmed, Khan, Shahjalal, dan Islam (2002), penggunaan jamur pada fermentasi membuat bahan pakan menjadi mudah dicerna sehingga jumlah mikroba yang meningkat menjadi lebih aktif dalam mendegradasi bahan pakan dan menyebabkan kenaikan kecernaan bahan organik.

Hal tersebut sejalan dengan pendapat Dewi dkk (2020) yang menyatakan bahwa tingginya populasi mikroba akan meningkatkan jumlah enzim sehingga kecernaan juga akan meningkat. Jika kecernaan meningkat maka nilai TDN juga meningkat karena besar kecilnya nilai energi TDN tergantung pada kecernaan bahan organik pakan yang meliputi protein kasar, serat kasar, lemak kasar dan BETN. Nilai TDN berhubungan erat dengan kandungan BO (Hermanto, 2001). Kecernaan bahan organik menggambarkan ketersediaan nutrien pakan (Suparwi, Irawan, dan Utami, 2012).

Dalam penelitian ini, nilai BETN semakin naik seiring dengan penggunaan konsentrasi jamur yang semakin tinggi. Peningkatan nilai BETN akan meningkatkan kecernaan bahan kering (KCBK), kecernaan bahan organik (KCBO) maupun TDN (Dewi dkk, 2020).

\section{Pengaruh perlakuan terhadap nilai pH}

Nilai $\mathrm{pH}$ merupakan salah satu faktor penting yang mempengaruhi kualitas fermentasi terutama kaitannya dengan daya simpan yang dihasilkan. Hasil rataan nilai $\mathrm{pH}$ dari fermentasi kulit ubi kayu dengan kadar Aspergillus oryzae yang berbeda disajikan pada Tabel 4.

Berdasarkan data pada Tabel 4, dapat dilihat bahwa hasil fermentasi kulit ubi kayu menggunakan Aspergillus oryzae dengan kadar berbeda memberikan pengaruh yang sangat nyata $(\mathrm{P}<0,01)$ terhadap nilai $\mathrm{pH}$ hasil fermentasi. Nilai rataan $\mathrm{pH}$ fermentasi kulit ubi kayu menggunakan Aspergillus oryzae mengalami penurunan seiring dengan bertambahnya kadar Aspergillus oryzae yang diberikan. Hasil Uji Jarak Berganda Duncan menunjukkan bahwa nilai rataan $\mathrm{pH}$ tertinggi adalah $\mathrm{P} 0$ yang 
memberikan pengaruh sangat nyata dibandingkan perlakuan lainnya. Nilai $\mathrm{pH}$ terendah adalah perlakuan P3 yang menunjukkan perbedaan sangat nyata dengan P0 dan P1, namun tidak ada perbedaan sangat nyata terhadap P2. Penggunaan tingkat konsentrasi Aspergillus oryzae yang semakin tinggi menunjukkan nilai $\mathrm{pH}$ semakin turun. Menurut Hidayati dkk (2013), perubahan nilai $\mathrm{pH}$ tersebut disebabkan oleh adanya aktivitas mikroorganisme menguraikan karbohidrat pada kulit ubi kayu selama proses fermentasi.

Tabel 4. Rataan nilai pH Hasil Fermentasi Kulit Ubi Kayu

\begin{tabular}{cc}
\hline Perlakuan & $\mathrm{pH}$ \\
\hline P0 & $6,32 \pm 0,04^{\mathrm{c}}$ \\
P1 & $6,32 \pm 0,04^{\mathrm{b}}$ \\
P2 & $5,34 \pm 012^{\mathrm{a}}$ \\
P3 & $5,23 \pm 0,09^{\mathrm{a}}$ \\
\hline
\end{tabular}

Keterangan: Superskrip yang berbeda pada kolom yang sama menunjukkan perbedaan yang sangat nyata $(\mathrm{P}<0,01)$ terhadap nilai $\mathrm{pH}$ fermentasi kulit ubi kayu.

Pemecahan karbohidrat tersebut menghasilkan asam organik yang menyebabkan nilai $\mathrm{pH}$ menjadi turun. Asam-asam organik tersebut diantaranya adalah asam piruvat, asam sitrat, asam suksinat, asam laktat dan asam asetat. Menurut Iskandar, Agustine, Sidik, Udin dan Karossi (1994), penurunan pH pada medium terjadi karena adanya akumulasi dari asam-asam organik hasil metabolisme kapang. Menurut Parbat dan Singhal (2011), produksi amilase tertinggi dengan fermentasi menggunakan Aspergillus oryzae didapatkan pada $\mathrm{pH}$ 5. Pada $\mathrm{pH}$ 5, Aspergillus oryzae dapat menghasilkan aktivitas amilase yang tertinggi $(283,866$ unit). Hal ini dikarenakan pH 5 merupakan kondisi lingkungan $A$. oryzae memfermentasi substrat. Hal ini sesuai dengan fungsi utama enzim yaitu sebagai katalis pendukung pertumbuhan dan metabolisme mikroorganisme di lingkungannya (Juwana dkk, 2018). Menurut Mufarrikha, Roosdiana, Prasetyawan (2014), pada pH 5 dihasilkan konsentrasi protein hasil fermentasi terbaik yaitu 8267 ppm. Aktivitas pektinase hasil fermentasi tertinggi dihasilkan pada $\mathrm{pH} 5$ dari kisaran $\mathrm{pH}$ 5-10 dan semakin menurun pada kondisi basa, karena pada umumnya kapang (Aspergillus niger) menyukai $\mathrm{pH}$ di bawah 7 . Kondisi $\mathrm{pH}$ lingkungan medium yang optimum akan mendukung produksi enzim yang lebih maksimum. Fermentasi sangat bergantung pada sel dan akan tumbuh baik pada $\mathrm{pH} 5$ karena enzim-enzim yang bekerja untuk metabolisme tumbuh baik pada $\mathrm{pH}$ 5. Hal tersebut juga sesuai dengan Ingrid dan Suharto (2012) yang menyatakan bahwa $\mathrm{pH}$ medium untuk memproduksi asam glukonat berada pada rentang 4,5-7. Pada $\mathrm{pH}$ 5,5 dianggap sebagai $\mathrm{pH}$ optimum untuk Aspergillus niger. Pada tahap awal terjadi penurunan $\mathrm{pH}$ mencapai nilai minimal antara 4,40-5,84 sampai dengan hari ke-4 fermentasi, setelah itu terjadi kenaikan sampai dengan akhir fermentasi (hari ke-10) mencapai nilai maksimal antara 7,47-8,32 (Pudjiraharti, Udin dan Karossi, 1997).

\section{KESIMPULAN}

Kesimpulan yang dapat diambil dari hasil penelitian yaitu fermentasi kulit ubi kayu menggunakan level Aspergillus oryzae yang berbeda $(0 \%, 1 \%, 2 \%$ dan $3 \%)$ memberikan peningkatan pada kualitas fermentasi. Perlakuan terbaik adalah perlakuan P3 yaitu penambahan kadar Aspergillus oryzae 3\% yang diinkubasi selama 96 jam dengan hasil kandungan HCN 55,82 mg/kg; TDN 72,92\% dan nilai pH 5,23. 


\section{DAFTAR PUSTAKA}

Adli, D. N., \& Sjofjan, O. (2020). Metaanalisis: pengaruh substitusi jagung dengan bahan pakal lokal terhadap kualitas karkas daging broiler. Jurnal Ilmu Peternakan Terapan, 3(2), 4448. https://doi.org/10.25047/jipt.v3i2. 1940

Ahmed, S., Khan, M. J., Shahjalal, M., \& Islam, K. M. S. (2002). Effects of feeding urea and soybean meal-treated rice straw on digestibility of feed nutrients and growth performance of bull calves. Asian-Australasian Journal of Animal Sciences, 15(4), 522-527. https://doi.org/10.5713/ajas .2002 .522

Aisjah, T. (2012). Bioprocess of winged bean seeds (Psophocarpus tetragonolobus (L) DC) BY rhizopus oligosporus to improved. jurnal ilmu ternak universitas padjadjaran, 12(1), 35-40. https://doi.org/10.24198/jit.v $12 \mathrm{I} 1.5135$

Akhadiarto, S. (2016). Pemanfaatan limbah kulit singkong, kulit pisang dan kulit kentang sebagai bahan pakan ternak melalui teknik fermentasi. Jurnal Teknologi Lingkungan, 10(3), 257263. https://doi.org/10.29122/jtl.v10i3 .1471

Anonim. (2011). Inovasi Pengolahan Ubi Kayu Meningkatkan Pendapatan dan Disverifikasi Pangan (4th ed.). Balai Besar Penelitian dan Pengembangan Pascapanen Pertanian Bogor.

Antari, R., \& Umiyasih, U. (2009). Pemanfaatan tanaman ubi kayu dan limbahnya secara optimal sebagai pakan ruminansia. Wartazoa, 19(4), 191-200.

Darmawan. (2006). Pengaruh kulit umbi ketela pohon fermentasi terhadap penampilan kambing jantan. Jurnal Ilmiah Ilmu-Ilmu Peternakan, 9(2), 115-122.

Dewi, O., Suryani, N. N., \& Mudita, I. M. (2020). The in-vitro digestibility of dry matter and organic matter of banana stem combined with kembang telang (Clitoria ternatea) silage. Jurnal Peternakan Tropika, 8(1), 61-73.

Feliana, F., Laenggeng, A. H., \& Dhafir, F. (2014). Kandungan gizi dua jenis varietas singkong (Manihot esculenta) berdasarkan umur panen di Desa Siney Kecamatan Tinombo Selatan Kabupaten Parigi Moutong. Jurnal EJipbiol, 2(3), 1-14.

Hartadi, H., Reksohadiprodjo, S., Lebdosukojo, S., \& Tillman, A. D. (1980). Tabel-tabel dari Komposisi Bahan Makanan Ternak Untuk Indonesia. International Feedstuffs Institute.

Hatma, A. T., Tampoebolon, B. I. M., \& Prasetiyono, B. W. H. E. (2018). Pengaruh Perbedaan Aras Starter dan Lama Fermentasi Terhadap Kadar Protein Kasar, Serat Kasar, dan TDN (Total Digestible Nutrient) Klobot Jagung Teramoniasi. Prosiding Seminar Nasional Kebangkitan Peternakan III.

Hermanto. (2001). Pakan Alternatif Sapi Potong. In Kumpulan Makalah Lokakarya Kajian Teknologi Pakan Ternak Alternatif. Fakultas Peternakan Universitas Brawijaya.

Hersoelistyorini, W., Utama, C. S., \& Suyanto, A. (2012). Aplikasi Proses Fermentasi Kulit Singkong Menggunakan Starter Asal Limbah Kubis dan Sawi Pada Pembuatan Pakan Ternak Berpotensi Probiotik. Seminar Hasil-Hasil Penelitian.

Hidayati, D., Ba'ido, D., \& Hastuti, D. S. (2013). Pola pertumbuhan ragi tape pada fermentasi kulit singkong. AGROINTEK, 7(1), 6-10. https:// doi.org/10.21107/AGROINTEK.V7I 1.2044

Ingrid, H. M., \& Suharto, I. (2012). Fermentasi Glukosa oleh Aspergillus niger Menjadi Asam Glukonat. Jurnal LPPM Universitas Katolik Parahayangan.

Iskandar, Y. M., Agustine, D., Sidik, A., Z. Udin, L., \& Karossi, A. T. (2017). 
Fermentasi alfa amilase dari aspergillus oryzae pada media sagu metroxylon. Jurnal Kimia Terapan Indonesia (Indonesian Journal of Applied Chemistry), 4(1), 48-49. https://doi.org/10.14203/jkti.v4i1.261

Juwana, A., Suryahendra, T., Lindayani, \& Hartayanie, L. (2015). Optimasi Suhu dan pH Crude Enzim Amilase Yang Dihasilkan Oleh Aspergillus Pada Media Kulit Pisang Kepok (Musa parasidiaca var formatypica). Pertemuan Ilmiah Tahunan Perhimpunan Mikrobiologi Indonesia. Mufarrikha, I., Roosdiana, A., \& Prasetywan, S. (2014). Optimasi kondisi produksi pektinase dari Aspergillus niger. Kimia Student, 2(1), 393-399.

Muhiddin, N. H., Djide, M. N., \& Das'ad, S. (2015). Kandungan protein dan HCN "Wikau Maombo" hasil fermentasi umbi ubi kayu pahit (Manihot aipi Phol) menggunakan beberapa isolat mikroorganisme lokal. Sainsmat: Jurnal Ilmiah Ilmu Pengetahuan Alam, 2(2), 161-172. https://doi. org/10.35580/SAINSMAT228622013

Muhiddin, N. H., Juli, N., \& Aryantha, P. N. (2001). Peningkatan kandungan protein kulit umbi ubi kayu melalui proses fermentasi. JMS, 6(1), 1-12.

Nurlaili, F., Suparwi, \& Sutardi, T. R. (2013). Fermentasi kulit singkong (Manihot Utilissima Pohl) menggunakan aspergillus niger pengaruhnya terhadap kecernaan bahan kering (kbk) dan kecernaan bahan organik (KBO) secara in-vitro. Jurnal Ilmiah Peternakan, 1(3), 856-864.

Parbat, R., \& Singhal, B. (2011). Production of glucoamylase by aspergillus oryzae under solid state fermentation using agro industrial products. International Journal Of Microbiological Reseach, 2(3), 204-207.

Pudjiraharti, S., Pudjiraharti, S., Udin, L. Z., \& Karossi, A. T. (2017). Produksi alfa-amilase oleh aspergillus oryzae dalam media pati sagu (Metroxylon sp.). Jurnal Kimia Terapan Indonesia (Indonesian Journal of Applied Chemistry), 7(1-2), 1-2. https://doi. org/10.14203/jkti.v7i1-2.221

Putri, S. W. A., \& Hersoelistyorini, W. (2012). Kajian kadar protein, serat, hcn, dan sifat organoleptik prol tape singkong dengan substitusi tape kulit singkong. Jurnal Pangan Dan Gizi, 3(1), 17-27. https://doi.org/10.26714/ JPG.3.1.2012.\%P

Rasulu, H., Sudarminto, S. Y., \& Kusnadi, J. (2012). Karakteristik tepung ubi kayu terfermentasi sebagai bahan pembuatan sagukasbi. Jurnal Teknologi Pertanian, 13(1), 1-7.

Santi, O., Ratnadewi, A. A. I., Handayani, W., \& Santoso, A. B. (2015). Isolasi Xilan dari Kulit Singkong dan Uji Reaktivitasnya Terhadap Enzim Endo - $\beta$ - 1,4 Xilanase. Prosiding Seminar Nasional Kimia.

Sari, Fi. D. N., \& Astili, R. (2018). Kandungan asam sianida dendeng dari limbah kulit singkong. Jurnal Dunia Gizi, 1(1), 20-29. https://doi.org/ 10.33085/jdg.v1i1.2899

Simbolon, N., Iswarin Pujaningsih, R., \& Mukodiningsih, S. (2016). Pengaruh berbagai pengolahan kulit singkong terhadap kecernaan bahan kering dan bahan organik secara in vitro, protein kasar dan asam sianida. Jurnal IlmuIlmu Peternakan, 26(1), 58-65. https://doi.org/10.21776/ub.jiip.2016. 026.01 .9

Sjofjan, O., Nur Adli, D., Djunaidi, I., \& Kuncoro, K. (2020). Utilization of biogas liquid waste for starter in the fermentation of rice husk as a potential feed for poultry. ANIMAL PRODUCTION, 22(1), 24-30. https:// doi.org/10.20884/1.jap.2020.22.1.38

Steel, R. G., \& Torrie, J. H. (1993). Prinsip dan Prosedur Statistika (Pendekatan Biometrik) (2nd ed.). Gramedia Pustaka Utama.

Suparwi, Irawan, I., \& Utami, S. (2012). Kecernaan Bahan Organik dan kadar Amonia Onggok yang Difermentasi 
dengan Aspergillus niger secara In Vitro. Prosiding Seminar Nasional "Pengembangan Sumber Daya Pedesaan Dan Kearifan Lokal Berkelanjutan II", 226-231.

Suroso, E. (2011). Model Proses Produksi Industri Tapioka Ramah Lingkungan Berbasis Produksi Bersih (Studi Kasus Di Provinsi Lampung). Institut Pertanian Bogor.

Suryani, H., Zain, M., Jamarun, N., \& Ningrat, R. W. S. (2015). Peran direct fed microbials (DFM) saccharomyces cerevisiae dan aspergillus oryzae terhadap produktivitas ternak ruminansia: review. Jurnal Peternakan Indonesia (Indonesian Journal of Animal Science), 17(1), 27-37. https://doi.org/10.25077/jpi. 17.1.2737.2015

Syamsu, J. A., \& Abdullah, A. (2009). Analisis strategi pemanfaatan limbah tanaman pangan sebagai pakan ruminansia di Sulawesi Selatan. Jurnal Ekonomi Pembangunan: Kajian Masalah Ekonomi Dan Pembangunan, 10(2), 199-214. https://doi.org/10. 23917/jep.v10i2.800

Tanuwiria, U. H., Mushawwir, A., \& Yulianti, A. (2007). Potensi pakan serat dan daya dukungnya terhadap populasi ternak ruminansia di wilayah kabupaten garut. Jurnal Ilmu Ternak Universitas, 7(2), 117-127.

Wangari, M. F. (2013). Potential Toxic Levels Of Cyanide In Cassava (Manihot esculenta Crantz) Grown In Some Parts Of Kenya. Kenyatta University.

Wijayanti, E., Wahyono, F., \& Surono. (2012). Kecernaan nutrien dan fermentabilitas pakan komplit dengan level ampas tebu yang berbeda secara in vitro. Animal Agricultural Journal, 1(1), 167-179.

Yuliana, A., \& Chuzaemi, S. (2019). Pengaruh lama fermentasi ampas putak (Corypha gebanga) terhadap kualitas fisik dan kualitas kimia menggunakan aspergillus oryzae. Jurnal Nutrisi Ternak Tropis, 2(1), 19-32. https://doi.org/10.21776/ub.jnt .2019 .002 .01 .3

Yuliati, L., Nasir, M. A., \& Subagiarta, I. W. (2019). Analisis Daya Saing Komoditas Singkong Kabupaten Jember Di Jawa Timur. Prosiding Seminar Nasional Penelitian \& Pengabdian Kepada Masyarakat, 452-457. 